\title{
Instability in cointegration regressions: a brief review with an application to money demand in Portugal
}

\author{
VASCO J. C. R. DE A. GA BRIEL, ARTUR C. B. DA SILVA LOPESz \\ and LUIS C. NUNES*X \\ Escola de Economia e Gestao, Universidade do Minho, Campus de Gualtar, P- \\ 4710-057 Braga, Portugal, zInstituto Superior de Economia e Gestào, \\ Universidade Técnica de Lisboa, Rua do Quelhas 6, P-1200-781 Lisboa, Portugal \\ and xFaculdade de Economia, Universidade Nova de Lisboa, Tv Estevao Pinto, \\ P-1099-032 Lisboa, Portugal
}

This study addresses some modelling questions related to the possibility of structural change in models with nonstationary variables. Focusing on cointegration issues, some methodological aspects are discussed, attempting to integrate coherently the several steps of the modelling strategy. These range from unit root to cointegration testing and to testing for instability in the cointegration vector. An empirical example with Portuguese data tries to illustrate the usefulness of this approach, where a simple money demand function is estimated using an error-correction model (ECM). If a break is explicitly allowed in the cointegration vector the forecasting performance of the ECM improves.

*Corresponding author. E-mail : lcnunes@fe.unl.pt 